\title{
Secondary fermentation in the rumen of a sheep given a diet based on molasses
}

\author{
BY J. B. ROWE,* MARION L. LOUGHNAN, J. V. NOLAN AND \\ R. A. LENG \\ Department of Biochemistry and Nutrition, University of New England, \\ Armidale, NSW 235 I, Australia
}

(Received 28 June 1978 - Accepted 21 September 1978)

\begin{abstract}
I. The extent of conversion of acetate-carbon to carbon dioxide in the rumen of a $40 \mathrm{~kg}$ wether consuming I $\mathrm{kg}$ molasses/d was estimated using isotope-tracer-dilution techniques.

2. There was a high rate of conversion of acetate to $\mathrm{CO}_{2}(6.0 \mathrm{~g} \mathrm{C} / \mathrm{d})$ in the rumen. There were high concentrations in the rumen of Methanosarcina approximately $6 \times 10^{\circ} / \mathrm{ml}$ which represents a significant proportion of the rumen bacterial biomass. These organisms are usually found in mud and sludge and are capable of oxidizing acetate.

3. The most likely explanation of these results was that there was an extensive secondary or sludge-type fermentation occurring in the rumen which results in volatile fatty acids being converted to $\mathrm{CO}_{2}$ and methane. In similar studies with sheep given lucerne (Medicago sativa) diets, conversion of acetate- $\mathrm{C}$ to $\mathrm{CO}_{2}$ within the rumen was not evident.

4. It is suggested that a major effect of the presence of secondary fermentation processes in the rumen may be to reduce availability of energy nutrients to the animal, and to alter the ratio protein :energy in the absorbed nutrients.
\end{abstract}

The major source of energy nutrients to ruminant animals is the volatile fatty acids (VFA) produced during fermentation in the rumen. It is generally assumed that most of the VFA produced are absorbed and provide energy to the animal and that the utilization of VFA in the rumen is negligible, but this may not always be true.

There are good relationships between the entry rates and concentrations of each VFA in the rumen fluid of sheep for a wide range of diets based on cereals and dry herbage (see Leng, 1974). However, in studies with sheep in which molasses was the major dietary component, the concentration of acetate in the rumen fluid was far lower, for any given acetate entry rate, than in animals given roughage-based diets (J. B. Rowe, unpublished observations). This finding led us to examine the utilization of acetate in the rumen of molasses-fed sheep. In this study, estimates of the interconversions between rumen acetate-carbon and blood and rumen carbon dioxide were obtained by a method of isotope-tracer analysis developed by Nolan et al. (1976). The results indicated that there was appreciable conversion of acetate-C to $\mathrm{CO}_{2}$ within the rumen of sheep given molasses-based diets whereas there was negligible conversion in earlier studies with sheep given lucerne (Medicago sativa) diets.

\section{EXPERIMENTAL}

\section{Animals and diet}

A mature Merino $\times$ Border Leicester wether ( 3 years old) weighing approximately $40 \mathrm{~kg}$ and prepared with a rumen cannula was used. The animal was given free access each day to I $\mathrm{kg}$ molasses mixture containing $(\mathrm{g} / \mathrm{kg}): 910$ molasses, 30 urea, 45 water, 7.5 rock phosphate, 2.5 sodium chloride, 5 trace element mixture (Susta-Vet-R; Bristol Veterinary Products). In

* Present address: Consejo Estatal del Azúcar, Division Ceagana, km 10-1/2 Carretera Mella, Santo Domingo, Dominican Republic. 
addition $100 \mathrm{~g}$ chaffed oat straw and $80 \mathrm{~g}$ soya-bean meal were given at 08.00 hours each day.

\section{Experimental procedures}

Infusions of $\mathrm{NaH}^{14} \mathrm{CO}_{3}$ or $\left[\mathrm{U}-{ }^{14} \mathrm{C}\right]$ acetate into the rumen or of $\mathrm{NaH}^{14} \mathrm{CO}_{3}$ into the blood were each made at approximately $2 \mathrm{~d}$ intervals. Constant infusions of isotope were made intravenously (at approximately $0.3 \mu \mathrm{Ci} / \mathrm{min} ; 0.2 \mathrm{ml} / \mathrm{min}$ ) via a catheter into the jugular vein and intraruminally (at $0.5 \mu \mathrm{Ci} / \mathrm{min} ; \mathrm{I} \mathrm{ml} / \mathrm{min}$ ) via a polyethylene tube positioned near the middle of the dorsal sac. Each infusion was continued for $12 \mathrm{~h}$ and samples of rumen fluid and blood were taken each hour over the last $6 \mathrm{~h}$ of the infusion.

\section{Chemical methods}

The specific radioactivities of $\mathrm{CO}_{2}$ in the rumen fluid and blood, and of acetate in rumen fluid were estimated as described by Leng \& Leonard (I965).

\section{Microbiological examinations}

Protozoa in the rumen were counted using the method described by Warner (1962).

When counting protozoa large numbers of Sarcina-like organisms were observed. These organisms are readily recognized since they form window-pane colonies.

The colonies were counted in the same way as protozoa but using a chamber with $0.1 \mathrm{~mm}$ depth.

\section{Calculations}

The methods of analysis of the isotope-tracer results have been described by Nolan et al. (1976). Briefly, for each isotope infusion, the rate of irreversible loss of $\mathrm{C}$ from the primary compartment, and the proportions of $\mathrm{C}$ in each of the secondary compartments derived from the primary compartment were estimated (Table I). Then, assuming that the animal's metabolism was similar during each infusion, the three sets of values were combined to give a unique solution to a general three compartment model using the procedures outlined by Nolan et al. (1976).

\section{RESULTS}

The population density of protozoa (mainly Entodinia) was on average $4 \cdot 2 \times 10^{5}$ protozoa $/ \mathrm{ml}$ rumen fiuid.

The Sarcina-like organisms were identified as Methanosarcina since they were grampositive, non-motile cocci approximately $2 \mu \mathrm{m}$ in diameter which formed colonies of sixtyfour and exhibited blue-green fluorescence in ultraviolet light (see Mink \& Dugan, 1977; Bryant, I974). In four sheep on this diet there were (on average) approximately $10^{8}$ colonies $/ \mathrm{ml}$ or $6.4 \times 10^{9}$ organisms $/ \mathrm{ml}$.

The dense population of Methanosarcina is shown in Plate $\mathrm{I}$.

The rate of irreversible loss of acetate- $\mathrm{C}$ and $\mathrm{CO}_{2}-\mathrm{C}$ from rumen fluid and blood, and the proportions of each compartment arising from the other two pools are given in Table I for a sheep on a molasses-based diet. The flows of $\mathrm{C}$ involved in the production and interconversions of acetate and $\mathrm{CO}_{2}$ in the rumen and blood are given in Fig. I. In the sheep given molasses, $44 \mathrm{~g} \mathrm{C} / \mathrm{d}$ entered blood $\mathrm{CO}_{2}$ from rumen acetate; there was considerable direct transfer of rumen acetate- $\mathrm{C}$ into the rumen $\mathrm{CO}_{2}$ compartment $(6 \circ \mathrm{g} \mathrm{C} / \mathrm{d})$. This transfer did not represent acetate oxidation in the tissues since this $\mathrm{C}$ did not pass through the blood $\mathrm{CO}_{2}$ compar tment (see Fig. I). 
Table I. Results from which a kinetic model of carbon metabolism was derived for a sheep given a molasses-based diet

(Each set of results consists of values for the rates of irreversible loss of carbon from rumen acetate, rumen carbon dioxide, and blood carbon dioxide, and for the proportions of $\mathrm{C}$ in any two of the compartments derived from the primary compartment (compartment $j^{*}$ ) as determined in separate tracer-dilution experiments)

\begin{tabular}{|c|c|c|c|c|}
\hline & $\begin{array}{c}\text { Rate of } \\
\text { irreversible } \\
\text { loss from } \\
\text { compartment } \mathrm{j} \\
\text { (g C/d) }\end{array}$ & $\begin{array}{c}\text { Rumen } \\
\text { acetate-C } \\
\text { from } \\
\text { compartment } \mathrm{j} \\
(\%)\end{array}$ & $\begin{array}{c}\text { Rumen } \\
\mathrm{CO}_{2}-\mathrm{C} \\
\text { from } \\
\text { compartment } \mathrm{j} \\
(\%)\end{array}$ & $\begin{array}{c}\text { Blood } \\
\mathrm{CO}_{2}-\mathrm{C} \\
\text { from } \\
\text { compartment } \mathrm{j} \\
(\%)\end{array}$ \\
\hline \multicolumn{5}{|c|}{ Compartment $\mathrm{j}$ rumen } \\
\hline Acetate & 87 & - & $13 \cdot 2$ & $2 I \cdot 3$ \\
\hline $\mathrm{CO}_{2}$ & 113 & $2 \cdot 0$ & 一 & $39 \cdot 0$ \\
\hline Blood $\mathrm{CO}_{2}$ & 195 & $2 \cdot 6$ & $36 \cdot 0$ & 一 \\
\hline
\end{tabular}

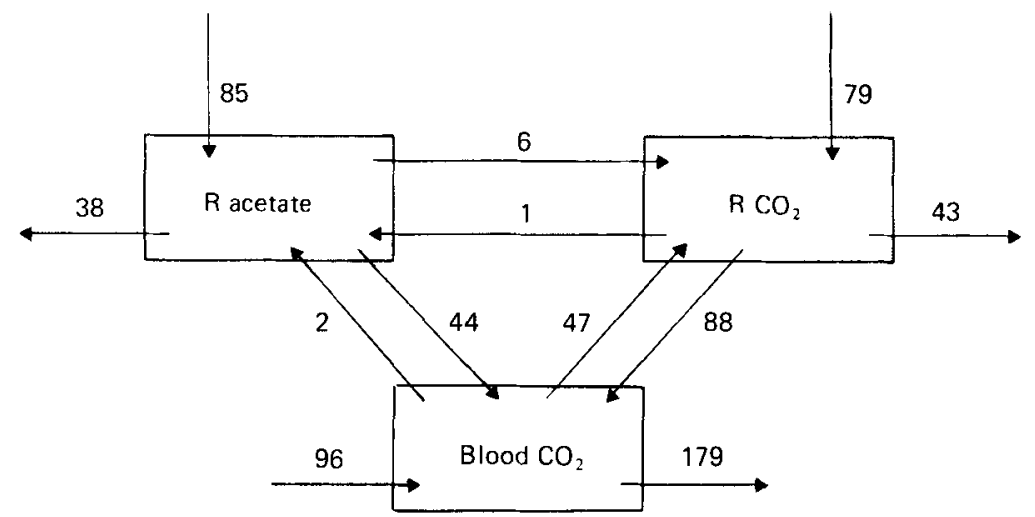

Fig. I. The flows of carbon ( $\mathrm{g} \mathrm{C} / \mathrm{d}$ ) involved in the production and interconversion of rumen fluid

(R) acetate, $\mathrm{R}$ carbon dioxide and blood $\mathrm{CO}_{2}$ in a sheep given a molasses-based diet.

\section{DISCUSSION}

The conversion of acetate- $\mathrm{C}$ to $\mathrm{CO}_{2}$ within the rumen (the formation of $\mathrm{CO}_{2}$ from acetate in the body having been accounted for separately) was unexpected, since we have not obtained quantitively important movements of $\mathrm{C}$ via this pathway in sheep given lucerne chaff. Acetate is a starting material for many synthetic processes in rumen microorganisms (Sauer et al. 1975) and lysis and subsequent digestion of microbial protein might be considered to be a possible route for $\mathrm{CO}_{2}$ production from acetate. However, the pathways of acetate utilization for amino acid synthesis in rumen microorganisms (see Sauer et al. 1975) and recycling of acetate-C through amino acids to acetate or propionate would result, in general, in the original $\mathrm{C}$ returning to the VFA molecules. It is unlikely therefore that this pathway accounts for the observed transfer of acetate- $\mathrm{C}$ to $\mathrm{CO}_{2}$. This is supported by the fact that little transfer of acetate-C to $\mathrm{CO}_{2}$ occurred within the rumen of sheep on diets of lucerne chaff (i.e. less than $0.5 \mathrm{~g} \mathrm{C} / \mathrm{d}$ ) even though approximately $20 \%$ of the microbial protein synthesized is apparently digested in the rumen (Nolan \& Leng, 1972).

The bacteria which formed the window-pane colonies (Plate I) were identified as Methanosarcina since they exhibited blue-green autofluorescence in ultraviolet light (M. L. Loughnan, M. J. Donelan \& R. A. Leng, unpublished observation). Autofluorescence of 
bacteria under ultraviolet light indicates the presence of Factor 420 and is a method for identifying methanogenic bacteria (Mink \& Dugan, 1977). Methanosarcina have been observed in rumen contents in small numbers (see Hungate, 1966) and isolated from marine mud and described by Stadtman \& Barker (I95I). They ferment acetate to $\mathrm{CO}_{2}$ and methane (Stadtman \& Barker, I95I) and rapid methanogenesis from acetate by a culture of Methanosarcina barkerii isolated from an anaerobic digester was reported recently (Mah et al. 1977).

The presence of appreciable numbers of Methanosarcina indicated that secondary fermentation in the rumen was occurring and this process provided the most likely explanation for the majority of the acetate-C converted to $\mathrm{CO}_{2}$ within the rumen of the sheep given the molasses-based diet. Although the total rumen bacterial count was not made in these sheep the concentration of Methanosarcina suggests that a significant proportion of the bacterial biomass in the rumen if total numbers of bacteria are taken to be approximately $5 \times 10^{10} / \mathrm{ml}$ (see Warner, 1962 ).

If it is assumed that most of the observed acetate-C transfer to $\mathrm{CO}_{2}$ is by acetate oxidation and I mol acetate is oxidized to $\mathrm{I} \mathrm{mol} \mathrm{CO}_{2}$ and $\mathrm{I}$ mol methane, then in this sheep approximately $14 \%$ of the rumen acetate was oxidized in the rumen. The energy lost as methane or heat in this way would reduce the metabolizable energy content of the diet considerably, particularly if both propionate and butyrate are also oxidized extensively in the rumen. Bacterial cell synthesis would be associated with the oxidation of VFA and therefore the net result of a secondary fermentation would be to decrease the availability of energy nutrients (VFA) but, if the bacteria responsible for the secondary fermentation become available for digestion in the lower tract, to increase the ratio protein : energy available to the animal.

In general bacteria capable of secondary fermentation may become more predominant in the rumen if there is a slow rumen turnover and a constant supply of VFA as substrate. The sheep given access to the molasses-based diets consumed small quantities of molasses at regular intervals. It was observed that the carbohydrates were so rapidly fermented in the rumen that, between intakes of molasses, there were long periods when soluble carbohydrates were not present in the rumen fluid but the VFA concentrations were fairly high and constant. During these periods, VFA-utilizing microorganisms would have a competitive advantage over organisms restricted to utilizing soluble carbohydrates; in addition, rumen fluid turnover appears to be extremely slow on this diet (see Marty \& Sutherland, 1970). This fact may also explain the relatively high density of rumen protozoa in sheep on this diet.

The mechanisms of acetate oxidation and the possibility that sludge-type organisms exist in the rumen of sheep on other diets is at present under investigation.

The authors wish to thank Mr F. M. Ball and Miss C. Allington for their expert assistance. Mr. J. B. Rowe was in receipt of an Australian Wool Research Committee Postgraduate Scholarship. 
British Journal of Nutrition, Vol. 4I, No. 2

Plate I

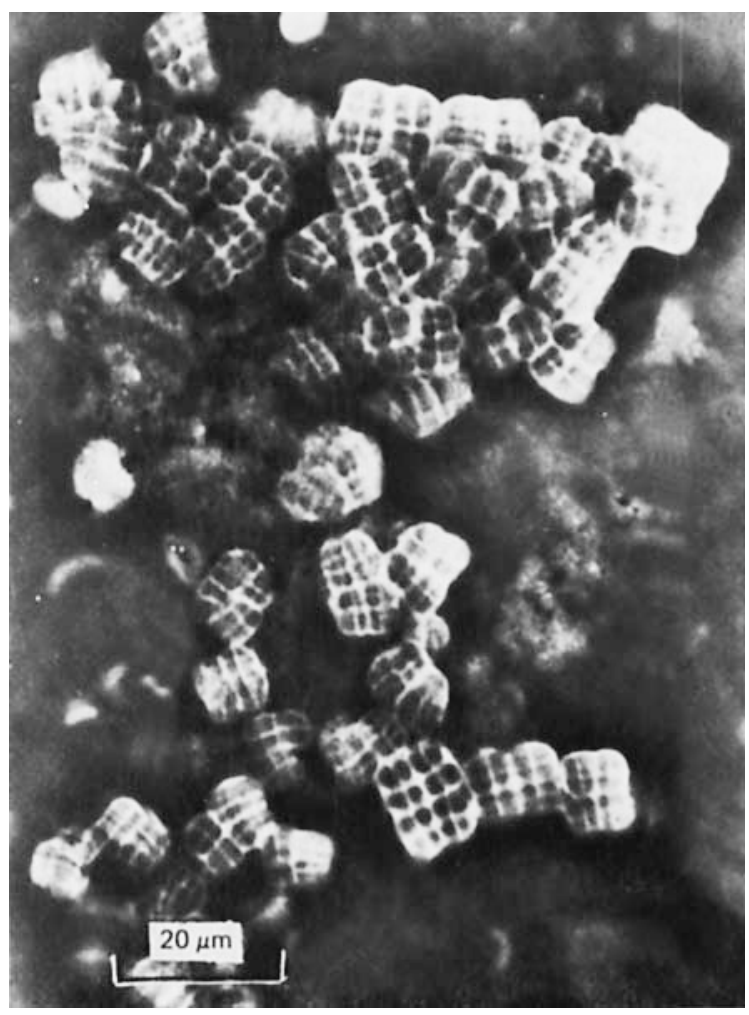




\section{REFERENCES}

Bryant, M. P. (1974). In Bergey's Manual of Determinative Bacteriology, 8th ed. [A. E. Buchanan and N. E. Gibbons, editors]. Baltimore: The Williams \& Wilkins Co.

Hungate, R. E. (1966). The Rumen and its Microbes. New York: Academic Press.

Leng, R. A. (1974). In Chemistry and Biochemistry of Herbage, chapter 30, p. 8I [R. W. Bailey and G. W. Butler, editors]. New York: Academic Press.

Leng, R. A. \& Leonard, G. J. (1965). Br. J. Nutr. 19, 469.

Mah, R. A., Ward, D. M., Baresi, L. \& Glass, T. L. (1977). A. Rev. Microbiol. 3r, 309.

Marty, R. J. \& Sutherland, T. M. (1970). Rev. cubana Cienc, agric. 4, 183.

Mink, R. W. \& Dugan, P. R. (1977). Appl. Environ. Microb. 33, 71 3.

Nolan, J. V. \& Leng, R. A. (1972). Br. J. Nutr. 27, 177.

Nolan, J. V., Norton, B. W. \& Leng, R. A. (1976). Br. J. Nutr. 35, 127.

Sauer, F. D., Erfle, J. D. \& Mahadevan, S. (1975). Biochem. J. 150, 357.

Stadtman, T. C. \& Barker, H. A. (1951). J. Bact. 61, 67.

Warner, A. C. I. (1962). J. gen. Microbiol. 28, 129.

\section{EXPLANATION OF PLATE}

Methanosarcina in rumen fluid from sheep given approximately $\mathrm{I} \mathrm{kg}$ molasses/d. Phase contrast ; magnification $\times 800$. 